\title{
10 \\ Evaluation of regional economic integration in East Asia
}

\author{
Shen Minghui
}

\section{East Asian regional economic integration}

Free trade agreements (FTAs) in East Asia have proliferated rapidly for the past two decades. At the end of February 2016, according to the Asian Development Bank (ADB) database, there were 133 FTAs in East Asia, of which 79 were signed and in effect, six were signed but not yet in effect, 44 were under negotiation and five involved signed framework agreements. Before the 1990s, economic integration in East Asia was driven mainly by market forces; it has been strengthened by institutional initiatives since then. Unlike the EU, the institutional arrangements in East Asia have been driven by a competitive pattern. Aside from the bilateral FTAs, the FTAs between the Association of Southeast Asian Nations (ASEAN) and a number of individual nations, known as the ASEAN+1 FTAs, have formed the major integration frameworks, with the ASEAN-China FTA as the spearhead. In the context of negotiations for the US-led Trans-Pacific Partnership (TPP), ASEAN initiated negotiations for the Regional Comprehensive Economic Partnership (RCEP) in 2012, involving 16 other countries. RCEP has now become a major framework for regional economic integration. 


\section{Development of regional economic integration}

The market has historically played a leading role in East Asian economic integration, backed by the market-friendly policies of regional governments (Zhang \& Minghui, 2012). Most East Asian economies have adopted export-oriented strategies, received foreign direct investments (FDIs) and participated in both regional and international production networks. With increasing intra-regional trade (see Figure 10.1) has come demands for tariff reductions and other arrangements, which have assisted in reducing the cost of doing business in East Asia.

ASEAN became a pioneer in regional trade agreements in East Asia by establishing its internal FTA and the ASEAN +1 FTAs. ${ }^{1}$ The Asian financial crisis in 1997 became a key factor in promoting East Asian regional cooperation because the spread of the crisis to other economies in the region required cooperative responses. The emergence of the ASEAN+3 cooperation framework was a direct response to the crisis. Two major institutions were initiated under this framework: the Chiang Mai Initiative, which has since made significant progress; and the East Asian FTA (EAFTA), which has become RCEP. RCEP is not simply a combination of the five existing ASEAN+1 FTAs; rather, it aims to create a high-level regional institution for economic integration and comprehensive cooperation.

1 The ASEAN FTA was signed in 1992, starting with the Common Effective Preferential Tariff (CEPT). Initially, it was signed by six members and four other new members subsequently joined. The ASEAN+1 FTAs started with the ASEAN-China FTA in 2002, which commenced with the signing of the ASEAN-China Comprehensive Economic Cooperation Framework Agreement and an Early Harvest Program. Other ASEAN+1 FTAs with Korea, Japan, Australia-New Zealand and India subsequently occurred. 
10. EVALUATION OF REGIONAL ECONOMIC INTEGRATION IN EAST ASIA

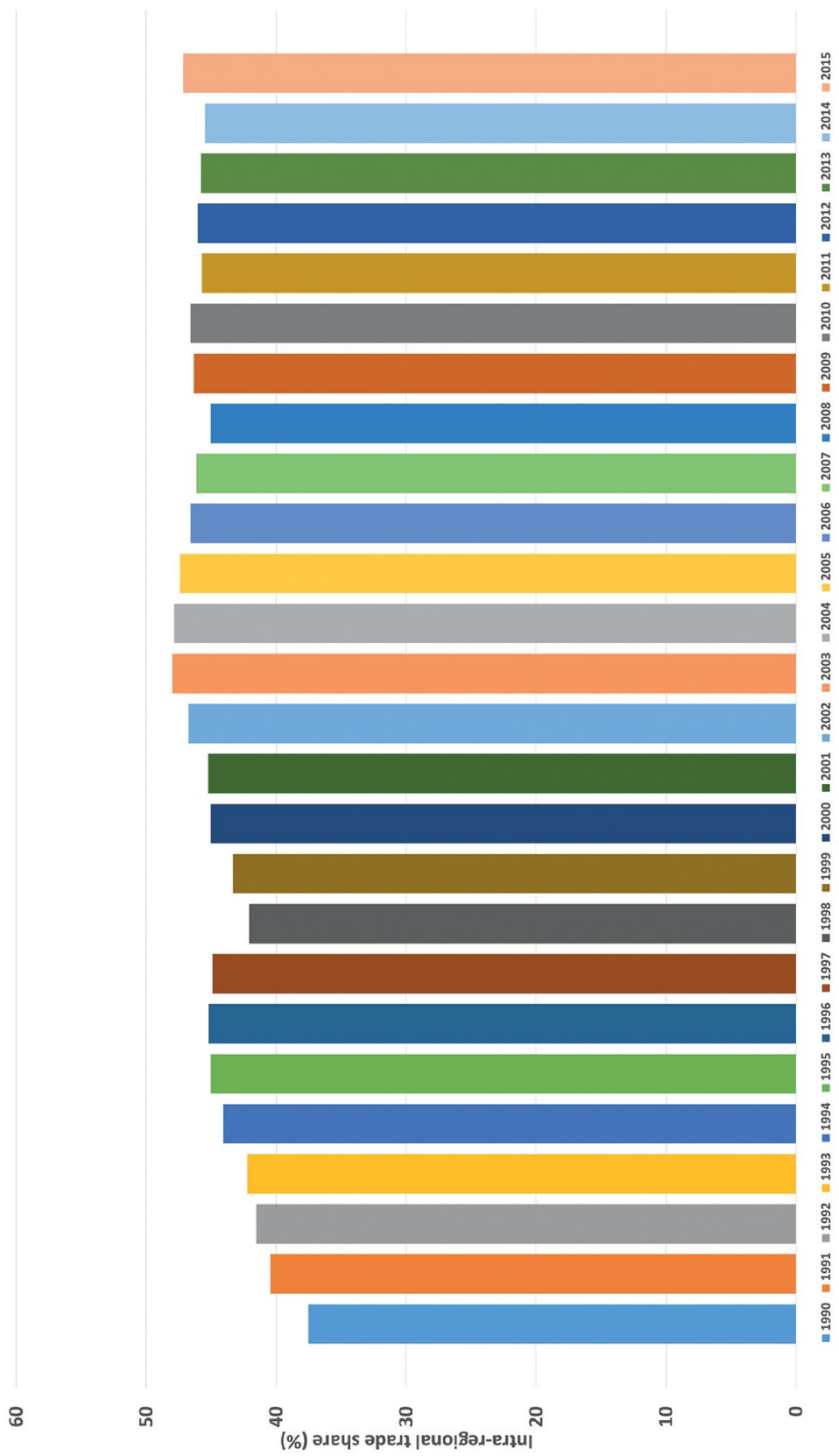

Figure 10.1: Intra-regional trade share of East Asia

Notes: The data cover ASEAN; China, including Hong Kong (China); Japan; and the Republic of Korea.

Source: Compiled using data from ADB (2016). 


\section{Characteristics of FTAs in East Asia}

Active latecomers in integration

Over time, more and more ASEAN members have desired to extend their trading spaces and this has spurred the flourishing of regional arrangements such as FTAs. The emergence of mega-FTAs, such as the North American Free Trade Agreement (NAFTA) and the EU, placed pressure on economies that were outside of those agreements because of the exclusive nature of regional trade blocs.

East Asian economies were latecomers to regional integration. There were only two FTAs in the region in 1991, and no others were formed between 1993 and 1998. However, since the 2000s, FTAs in East Asia have proliferated. In 2002, China and the ASEAN leaders signed the Framework Agreement on China-ASEAN Comprehensive Economic Cooperation. This triggered the negotiation of FTAs with ASEAN by other countries, including Japan, the Republic of Korea (ROK), India, Australia and New Zealand. In addition, East Asian economies have been active in negotiating bilateral FTAs within and across the region.

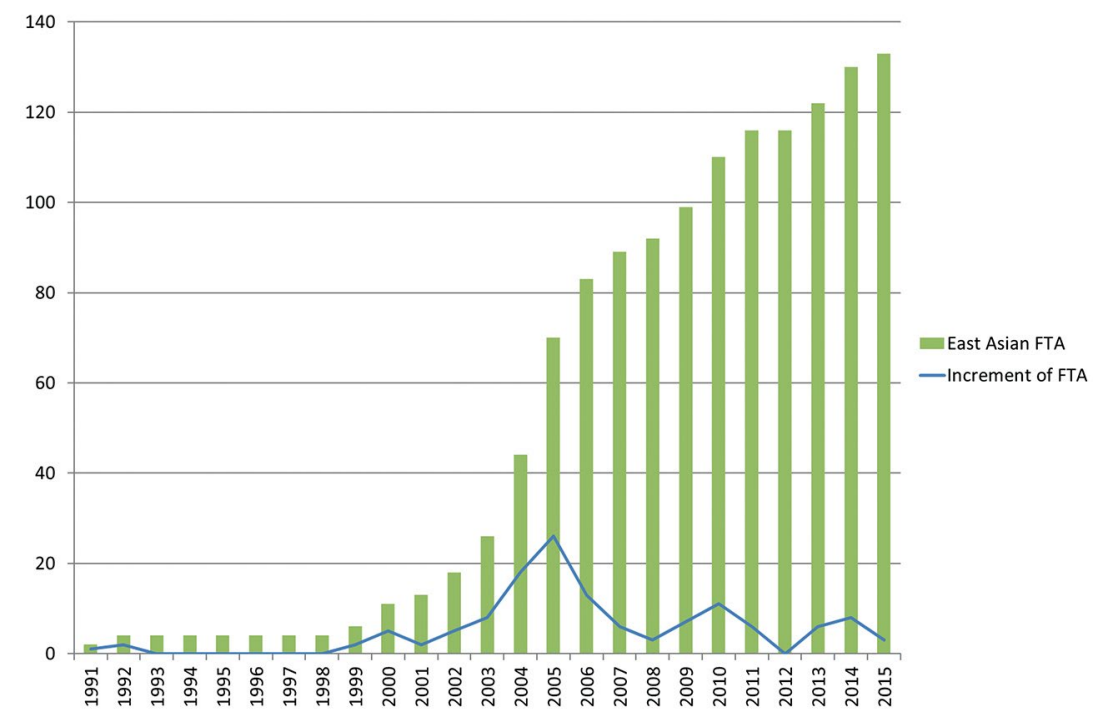

Figure 10.2: Free trade agreements in East Asia

Notes: The data cover ASEAN; China; Hong Kong (China); Taipei (China); Japan; and the Republic of Korea.

Source: Compiled using data from ADB FTA database (aric.adb.org/fta). 
Partly as a response to East Asian regional integration, the US actively took part in FTA negotiations with Singapore, Australia, ASEAN (through the US's Enterprise for ASEAN Initiative) and the ROK, which culminated in the US making the decision to lead the TPP negotiations. Fierce competition between the different partners contributed to the proliferation of regional FTAs in East Asia (Figure 10.2); there were 92 FTAs by 2008 and 133 by 2015 .

\section{Proliferation of bilateral FTAs}

Bilateral FTA negotiations are easier to conclude than multilateral or plurilateral negotiations because there are fewer players and narrower differences of interests. This factor, and the absence of a single powerful leader in East Asian regional integration, has contributed to the proliferation of bilateral FTAs. Most FTAs in East Asia are bilateral (see Figure 10.3).

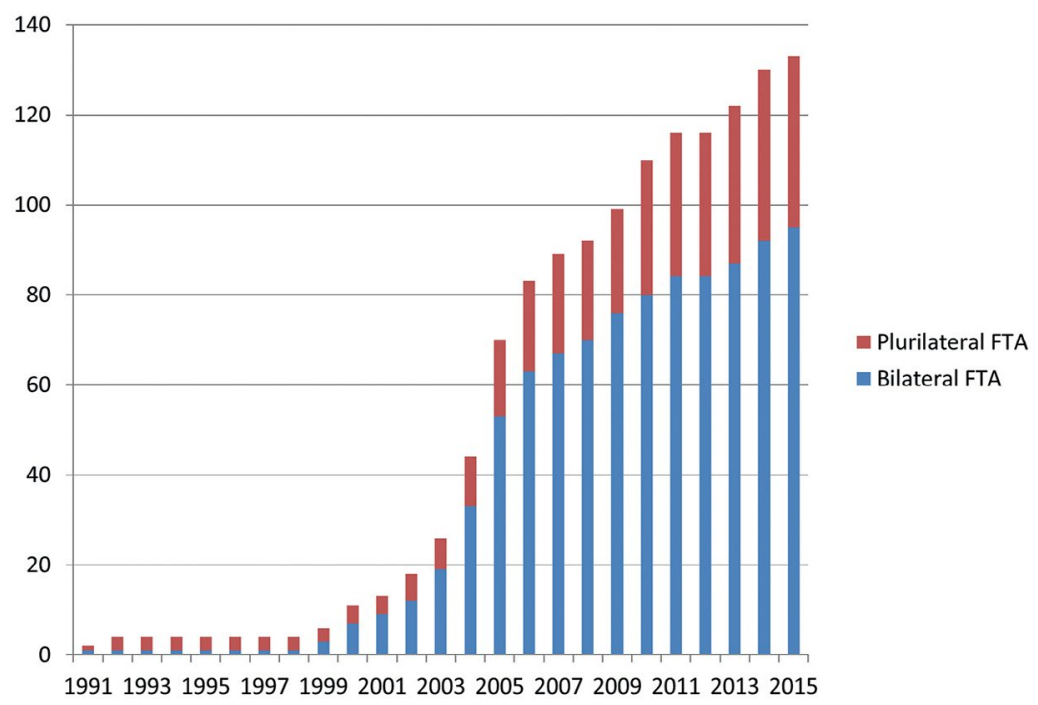

Figure 10.3: Bilateral free trade agreements and plurilateral FTAs in East Asia

Notes: The data cover ASEAN; China; Hong Kong (China); Taipei (China); Japan; and the Republic of Korea.

Source: Compiled using data from ADB FTA database (aric.adb.org/fta).

The pursuit of 'hub' status in regional integration has also promoted the proliferation of bilateral FTAs. According to the 'hub-and-spoke' theory, each hub economy obtains favourable access to spoke economies' markets, whereas spoke economies cannot achieve equal access to other spoke 
markets in the absence of FTAs. The advantage of being the one hub economy in Asia is clear; it provides incentives to the economies in the region to compete for the position. Under this terminology, an economy that has individually signed bilateral FTAs with many economies would serve as a hub. East Asia, Singapore and the ROK, in particular, have sought hub status for a long time and have made significant achievements in this direction. With a 77.2 per cent FTA coverage ratio, Singapore has been successful in maintaining a hub economy. It has concluded 13 FTAs with its important trade partners (ADB FTA database). ${ }^{2}$ As of 2016, ROK has launched FTA negotiations with eight economies and concluded 14 bilateral FTAs with trade partners. Benefiting from its hub status, the FTA coverage ratio of ROK also ranks highly, at 41.1 per cent.

\section{Practical approach to liberalisation}

FTAs in East Asia have developed rapidly in terms of quantity, but most have involved low degrees of liberalisation. Traditional issues, including tariff reduction, rules of origin (ROOs), technological barriers, inspection and quarantine, trade remedy and dispute settlement, have been covered in the FTAs. However, more complex issues, such as post-establishment national treatment, performance requirements, intellectual property rights, competition policy, ecommerce and environmental policy, have seldom been incorporated. In addition, sensitive issues, including labour movement and state-owned enterprises (SOEs) — which the TPP agreement did incorporate-have not been popular inclusions in most FTAs in the region.

In Asia, most FTAs have adopted a positive list approach concerning market access to trade in goods. A negative list approach was explored in the ASEAN-ROK FTA, in which long lists of sensitive items are excluded from the FTA provisions to protect domestic markets. In addition, four of the ASEAN+1 FTAs (the exception is for Australia and New Zealand in the ASEAN-Australia and New Zealand FTA) have failed to accomplish zero tariffs for all trade in goods. For ASEAN economies, 94.5 per cent of customs tariff lines have zero per cent tariffs in the ASEAN-China FTA, 93.3 per cent in the ASEAN-ROK FTA, 89 per cent in the ASEANJapan FTA, 75.6 per cent in the ASEAN-India FTA and 93.8 per cent in the ASEAN-Australia-New Zealand FTA. Moreover, the FTAs in the region usually involve tariff reduction or elimination periods of 10 years or more, and tariff reduction periods are extended further for some developing economies.

2 aric.adb.org/fta 
Table 10.1: ASEAN+1 free trade agreement coverage

\begin{tabular}{|c|c|c|c|c|c|c|}
\hline & & $\begin{array}{c}\text { ASEAN- } \\
\text { China }\end{array}$ & $\begin{array}{c}\text { ASEAN- } \\
\text { ROK }\end{array}$ & $\begin{array}{c}\text { ASEAN- } \\
\text { Japan }\end{array}$ & $\begin{array}{l}\text { ASEAN- } \\
\text { India }\end{array}$ & $\begin{array}{l}\text { ASEAN- } \\
\text { Australia- } \\
\text { NZ }\end{array}$ \\
\hline \multirow{6}{*}{$\begin{array}{l}\text { Trade in } \\
\text { goods }\end{array}$} & Tariff reduction & $\sqrt{ }$ & $\sqrt{ }$ & $\sqrt{ }$ & $\sqrt{ }$ & $\sqrt{ }$ \\
\hline & Rules of origin & $\sqrt{ }$ & $\sqrt{ }$ & $\sqrt{ }$ & $\sqrt{ }$ & $\sqrt{ }$ \\
\hline & Technology barriers & $\sqrt{ }$ & $\sqrt{ }$ & $\sqrt{ }$ & $\sqrt{ }$ & $\sqrt{ }$ \\
\hline & $\begin{array}{l}\text { Customs border } \\
\text { measures }\end{array}$ & * & * & $\sqrt{ }$ & & $\sqrt{ }$ \\
\hline & $\begin{array}{l}\text { Inspection and } \\
\text { quarantine }\end{array}$ & $\sqrt{ }$ & $\sqrt{ }$ & $\sqrt{ }$ & $\sqrt{ }$ & $\sqrt{ }$ \\
\hline & Trade remedy & $\sqrt{ }$ & $\sqrt{ }$ & $\sqrt{ }$ & $\sqrt{ }$ & $\sqrt{ }$ \\
\hline \multicolumn{2}{|c|}{ Trade in services } & $\sqrt{ }$ & $\sqrt{ }$ & $\sqrt{ }$ & & $\sqrt{ }$ \\
\hline \multirow[t]{3}{*}{ Investment } & $\begin{array}{l}\text { Post-establishment } \\
\text { national treatment }\end{array}$ & & $\sqrt{ }$ & $\sqrt{ }$ & & $\sqrt{ }$ \\
\hline & $\begin{array}{l}\text { Post-establishment } \\
\text { national treatment } \\
\text { Most-favoured } \\
\text { nation }\end{array}$ & $\sqrt{ }$ & $\sqrt{ }$ & $\sqrt{ }$ & & $\sqrt{ }$ \\
\hline & $\begin{array}{l}\text { Performance } \\
\text { requirement }\end{array}$ & & $\sqrt{ }$ & $\sqrt{ }$ & & $\sqrt{ }$ \\
\hline \multicolumn{2}{|c|}{ Intellectual property rights } & * & * & $\sqrt{ }$ & & $\sqrt{ }$ \\
\hline \multicolumn{2}{|c|}{ Government procurement } & & & $\sqrt{ }$ & & \\
\hline \multicolumn{2}{|c|}{ Competitive policy } & & & $\sqrt{ }$ & & $\sqrt{ }$ \\
\hline \multicolumn{2}{|c|}{ Ecommerce } & * & * & $\sqrt{ }$ & & $\sqrt{ }$ \\
\hline \multicolumn{7}{|l|}{ Labour } \\
\hline \multicolumn{2}{|c|}{ Environmental } & * & * & $\sqrt{ }$ & & \\
\hline \multicolumn{2}{|c|}{$\begin{array}{l}\text { Economic technological } \\
\text { cooperation }\end{array}$} & $\sqrt{ }$ & $\sqrt{ }$ & $\sqrt{ }$ & & $\sqrt{ }$ \\
\hline \multicolumn{2}{|c|}{ Dispute settlement } & $\sqrt{ }$ & $\sqrt{ }$ & $\sqrt{ }$ & $\sqrt{ }$ & $\sqrt{ }$ \\
\hline
\end{tabular}

Notes: The symbol * refers to an 'cooperation' or 'facilitation' arrangement instead of a binding agreement. ROK = the Republic of Korea; NZ = New Zealand.

Source: ADB FTA database (aric.adb.org/fta).

Concerning trade in services and investment, few of the World Trade Organization-plus (WTO-plus) commitments have been adopted in the above FTAs. Access to the regional market is limited. There is no chapter on investment in the ASEAN-India FTA and no post-establishment national treatment clause. There is no performance requirement in the ASEAN-China FTA. Generally, East Asian countries have adopted a practical and gradual approach to liberalising their markets for trade in goods, services and investment. 


\section{RCEP and regional production network reconfiguration}

In 2012, in response to the challenge presented by the TPP_-particularly from four of ASEAN's own participating members (Brunei, Singapore, Malaysia and Vietnam)_ASEAN decided to initiate RCEP for the remaining ASEAN+6 countries (China, ROK, Japan, India, Australia and New Zealand). Based on the guiding principles proposed by ASEAN, RCEP negotiations commenced in 2013. The aim of RCEP is to create an open market with a higher level of liberalisation than exists between the five ASEAN+1 FTAs by integrating the complex EAFTA networks and untangling the negative 'spaghetti bowl effect' in the region. The intensive FTA arrangements complicate ROOs and often result in red tape and cross-border procedures that increase transaction and time costs, reduce enterprises' operational efficiency, distort regional FDI and ignite trade protectionism. This process has a negative effect on East Asian production networks (Xiangyun, 2010).

RCEP is intended to deepen regional economic integration through further liberalisation of trade, services and investment and through harmonisation of the policies, rules and standards governing trade and investment. Therefore, RCEP is regarded as part of a supporting policy framework for deepening regional production networks and supply chains (Zhang \& Minghui, 2013).

\section{Moving towards an integrated framework}

\section{Diversified efforts country by country}

Owing to differences in industrial structure, sector development, trading status and economic development, the Asian regional economies proposed various FTA strategies to maximise their respective interests that had different, or even conflicting, aims. By insisting on the principle of ASEAN centrality, ASEAN is gradually upgrading its own institution from a free trade group to an economic community. At the same time, it has developed FTAs with other partners of the East Asian economies based on the ASEAN+1 formula. In 2012, as noted above, ASEAN initiated RCEP, which was aimed at building a comprehensive framework for liberalisation and economic cooperation, while retaining its own economic community as an independent identity. 
Since its accession to the WTO, China has actively participated in and promoted FTAs, including initiating the China-ASEAN FTA, chairing the EAFTA feasibility study and pushing the China-Japan-Korea FTA to support RCEP. These efforts have been motivated by the Chinese economy's deep integration within East Asia production networks. Since the TPP does not include China, East Asian economic integration has become even more important for it.

Under its 'Look East' policy, India has placed great importance on participating in East Asian integration and cooperation. India prioritised negotiating the ASEAN-India FTA and RCEP; however, given the difficulties India has faced in liberalising its domestic markets, it has not negotiated bilateral FTAs with Japan, Korea or China.

Japan plays a central role in East Asian production networks; however, until 2000, it did not take an active role in negotiating FTAs. Japan began its first FTA negotiation with Singapore in 2001 and signed this agreement at the end of 2002. Later, it began FTA negotiations with each ASEAN member individually. In 2006, Japan proposed the Comprehensive Economic Partnership for East Asia (CEPEA) as an alternative to EAFTA. In fact, RCEP is based on the framework proposed by the CEPEA report. Japan, ROK and China concluded an investment agreement in March 2012, and all three commenced negotiating a trilateral FTA in March 2013. However, Japan's participation in the TPP altered its priorities regarding the regional FTA strategy to some extent, as it gave more emphasis to the potential benefits of the TPP. ${ }^{3}$

ROK is an active player in negotiating FTAs with East Asian countries. In addition to having FTAs with ASEAN, Australia-New Zealand and China, ROK is the only country in East Asia that has concluded FTA negotiations with both the US and the EU. In addition, ROK is active in the negotiations for RCEP and the Korea-China-Japan FTA. As an export-oriented economy, ROK appears to be more active than many other countries in forging FTAs.

3 When President Trump announced that America would leave the TPP, Japan, which had ratified the TPP before all other TPP members, was severely disappointed. 
Australia and New Zealand have close economic relations with East Asia, which have encouraged them to participate in many types of regional economic integration, ranging from their ASEAN+1 FTA to RCEP. Australia and New Zealand are also involved in the TPP, which creates a much higher level of liberalisation than do the East Asia FTAs.

Although all the East Asian economies are interested in negotiating more FTAs with partners both inside and outside the region, they have common interests in forging an integrated FTA framework within East Asia.

\section{The rationale of RCEP}

Various simulation studies based on computerised general equilibrium modelling show that a region-wide FTA such as RCEP would reap more economic benefits than would bilateral or plurilateral FTAs (see Table 10.2). The economic gains for East Asia are significant if it moves from its current bilateral FTAs and ASEAN+1 FTAs towards RCEP (Kawai \& Wignaraja, 2007). Even when compared with the TPP, the income effect of RCEP remains significant. Therefore, RCEP could play an important role in creating an intra-regional market and promoting international trade.

RCEP will seek to promote greater regional economic integration, progressively eliminate both tariff and non-tariff barriers, and ensure consistency with the WTO's rules. RCEP is expected to tackle issues including trade in goods, trade in services, investment, economic and technical cooperation, intellectual property, competition policy and dispute settlement. An open accession scheme has been adopted to allow future members to join, provided they comply with RCEP's rules and guidelines.

Although market-driven economic integration has contributed greatly towards East Asian production networks and supply chains, many impediments remain to be addressed, including cross-border measures, non-compatible domestic rules, discriminatory regulations and red tape, which increases business costs (Kawai \& Wignaraja, 2009). Therefore, RCEP is regarded as part of the supporting policy framework for deepening regional production networks and supply chains. 


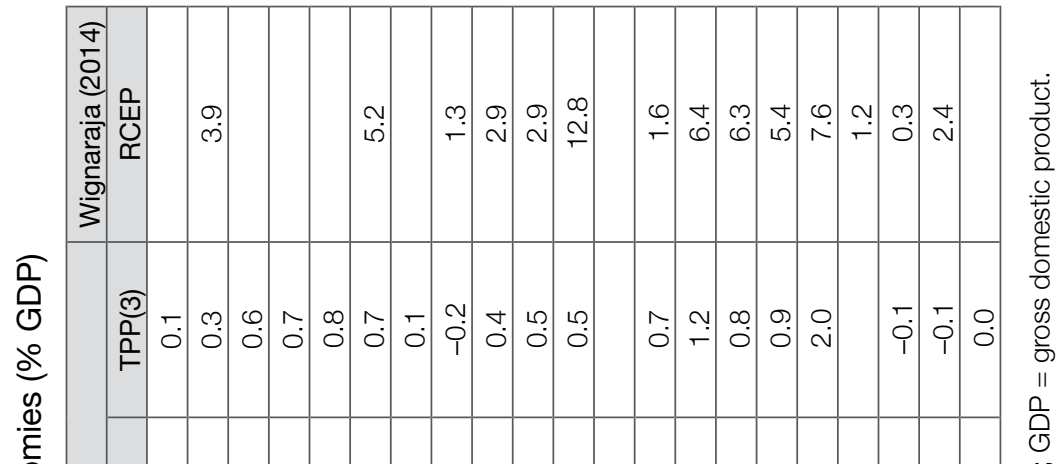



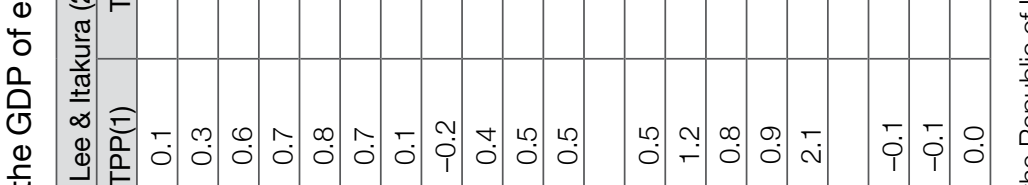

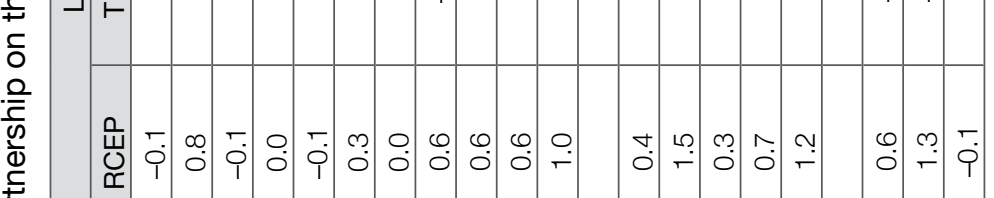

$\frac{1}{\frac{1}{2}}$

을

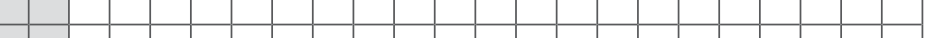

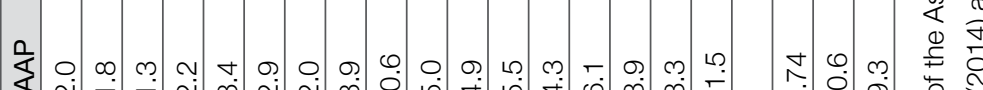

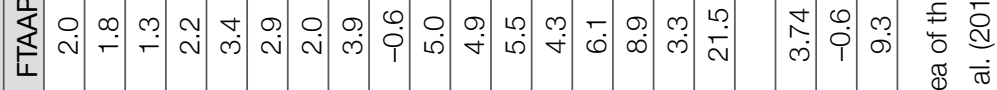



$\stackrel{0}{2}$

๙ิ

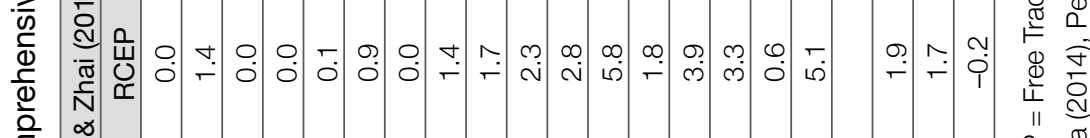

ठั

है

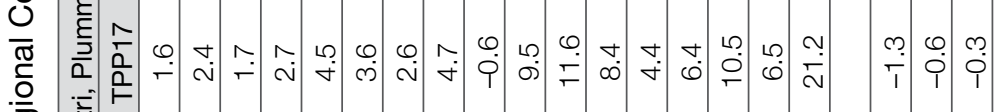



을

क्ष

$\square$

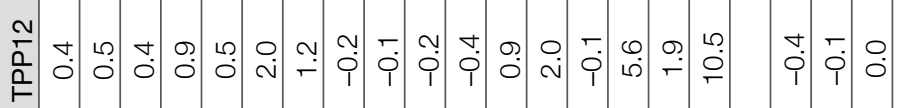

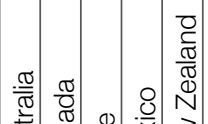

$\frac{\pi}{\infty} \stackrel{\infty}{\frac{\Phi}{0}}$

z 흐

志

苞

ì

웅

$\frac{0}{\frac{0}{0}}$

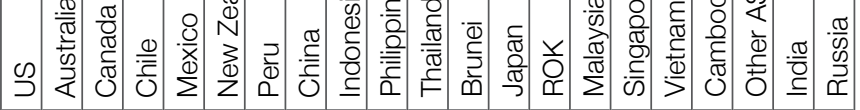

을 i 월 잉 II $\frac{\Phi}{S}$ 응 商敦 
Considering the large development gap between East Asian economies, one FTA will not be capable of meeting the diversified needs in the region. Therefore, flexible and differential treatment may emerge to better serve less-developed countries. Although it is expected that comprehensive coverage will be insisted on, more importance may be attached to growth and development issues. Further, priority will be given to promoting balanced development in the region. In the meantime, issues such as connectivity can be treated in the RCEP. Further, from a dynamic perspective, the gains from trade and investment facilitation and economic cooperation and connectivity under the framework of FTAs will be much greater than the gains from lowering tariffs only. This new kind of regional economic cooperation in East Asia will improve the long-term environment to promote regional investment and to strengthen development cooperation.

\section{The TPP and its effects}

\section{The nature of the TPP}

\section{Rule making by the US}

The US has been challenged by the emerging economies in the East Asian region and by the proliferation of intra-regional FTAs there; both the ASEAN+3 FTA and the ASEAN+6 FTA-potential paradigms of East Asian cooperation-exclude the US. Therefore, the US has become concerned about the emergence of a trade bloc in East Asia that will curtail its long-term interests. More importantly, the larger one country's economy is, and the bigger the export market that it can provide, the greater influence on international rule making it may have. The US has to participate in and lead the TPP to avoid being excluded by regionalism in East Asia, especially after its failure to conclude the Enterprise for the ASEAN Initiative, an agreement designed to facilitate commerce between the US and ASEAN towards an FTA.

In November 2000, China proposed an initiative called the ChinaASEAN FTA, triggering a series of FTAs in East Asia, most of which excluded the US. In 2004, the gross domestic product (GDP) of East Asia, calculated on the basis of the ASEAN+3, amounted to 69 per cent of US GDP. In 2006, based on the ASEAN+6, it reached 82 per cent of US GDP. Thus, by further strengthening their economic ties, it is possible for the East Asian economies to form a new economic bloc that 
could challenge the US leadership on international economic rules, with continuing consequences for US interests within the multilateral trading system. Former US president Barack Obama (2015), in his State of the Union address, asserted:

China wants to write the rules for the world's fastest-growing region. That would put our workers and our businesses at a disadvantage. Why would we let that happen? We should write those rules.

Later, Obama (2016a, 2016b) commented that 'with TPP, China doesn't set the rules in that region, we do' and that 'the TPP would let America, not China, lead the way on global trade'. Thus, one of the main reasons that the US determinedly promoted the TPP was to sustain its leadership in international trade rule making.

\section{Behind-the-border issues}

As a twenty-first century agreement, the TPP was comprehensive and of a high standard. Traditional chapters regarding trade in goods only accounted for a small part of the TPP. Most of the chapters addressed behind-the-border issues or WTO-X policy areas, which included investment, cross-border trade in services, financial services, temporary entry for business persons, telecommunications, ecommerce, government procurement, competition policy, SOEs and designated monopolies, intellectual property, labour, environment, regulatory coherence, transparency and anti-corruption (Horn, Mavroidis \& Sapir, 2010). Prior to the TPP, these WTO-X chapters had seldom been incorporated in existing FTAs in the region. Instead, developing economies had usually attached greater importance to traditional issues, such as trade in goods, customs and trade remedies.

Table 10.3: Comparison of negotiations areas between mega-free trade agreements and the WTO

\begin{tabular}{|l|c|c|c|c|}
\hline & TPP & TTIP & RCEP & WTO \\
\hline Trade in goods & $\sqrt{ }$ & $\sqrt{ }$ & $\sqrt{ }$ & $\sqrt{ }$ \\
\hline Trade remedies & $\sqrt{ }$ & $\sqrt{ }$ & $\sqrt{ }$ & $\sqrt{ }$ \\
\hline Trade facilitation & $\sqrt{ }$ & $\sqrt{ }$ & $\sqrt{ }$ & $\sqrt{ }$ \\
\hline Technical barriers to trade & $\sqrt{ }$ & $\sqrt{ }$ & $\sqrt{ }$ & $\sqrt{ }$ \\
\hline Sanitary and phytosanitary measures & $\sqrt{ }$ & $\sqrt{ }$ & $\sqrt{ }$ & $\sqrt{ }$ \\
\hline Trade in services & $\sqrt{ }$ & $\sqrt{ }$ & $\sqrt{ }$ & $\sqrt{ }$ \\
\hline Investment & $\sqrt{ }$ & $\sqrt{ }$ & $\sqrt{ }$ & $* *$ \\
\hline Intellectual property & $\sqrt{ }$ & $\sqrt{ }$ & $\sqrt{ }$ & $\sqrt{ }$ \\
\hline
\end{tabular}




\begin{tabular}{|l|c|c|c|c|}
\hline & TPP & TTIP & RCEP & WTO \\
\hline Competition policy, state-owned enterprises & $\sqrt{ }$ & $\sqrt{ }$ & $\sqrt{ }$ & \\
\hline Ecommerce & $\sqrt{ }$ & $\sqrt{ }$ & $*$ & \\
\hline Government procurement & $\sqrt{ }$ & $\sqrt{ }$ & & *** \\
\hline Environment & $\sqrt{ }$ & $\sqrt{ }$ & & \\
\hline Labour & $\sqrt{ }$ & $\sqrt{ }$ & & \\
\hline Dispute settlement & $\sqrt{ }$ & $\sqrt{ }$ & $\sqrt{ }$ & $\sqrt{ }$ \\
\hline Cross-cutting issues & $\sqrt{ }$ & $\sqrt{ }$ & & \\
\hline Standards and conformance, regulatory cooperation & & $\sqrt{ }$ & & \\
\hline
\end{tabular}

Notes: The symbol * indicates that the area is not explicitly stated as the category of negotiation but is included in other negotiating areas; ${ }^{*}$ indicates that the area is only under negotiation in trade-related investment measures (TRIM); ${ }^{\star \star \star}$ indicates that the area is under negotiation in plurilateral agreements. TPP = Trans-Pacific Partnership; TTIP = Transatlantic Trade and Investment Partnership; RCEP = Regional Comprehensive Economic Partnership; WTO = World Trade Organization .

Source: Japan External Trade and Research Organization (2015, p. 44).

In terms of the agreement's text, the TPP focused on behind-the-border issues, such as intellectual property rights, labour and SOEs. These highstandard clauses represent the interests of sectors in which the US has a competitive edge. In short, the TPP was expected to create a potential platform for economic integration across the Asia-Pacific region, expanding US exports and advancing US economic interests with the fastest-growing economies in the world (Bergsten \& Schott, 2010).

\section{Model for the Asia-Pacific and WTO}

European countries have historically challenged the US's dominance in writing international economic rules through the forum of the European Community, subsequently expanded to the EU-a unified economy possessing equal consumption market status to the US. For instance, in the early 1980s, after meeting strong resistance from the European Community, the US's attempt to open a new round of multilateral trade negotiations failed. Later, the US launched a US-Canada FTA, which forced European countries to agree to launch the Uruguay Round of trade negotiations. Subsequently, to break the persistent impasses of the Uruguay Round caused by the EU's refusal to compromise on issues concerning agricultural products, the US decided to negotiate with Canada and Mexico to establish NAFTA, which led to a prompt conclusion of the Uruguay Round. In this way, new issues, such as intellectual property rights, services and investment, eventually became incorporated into the General Agreement on Tariffs and Trade (GATT). 
10. EVALUATION OF REGIONAL ECONOMIC INTEGRATION IN EAST ASIA




The US expected to negotiate the TPP with a group of like-minded trading partners and then to offer incentives for other economies to join over time. The TPP, like NAFTA, could have served as an incubator for new trade rules, providing a template for future negotiations in the AsiaPacific region and in the multilateral system (Goodman, 2013, p. 4). Specifically, the US hoped to influence emerging economies in East Asia by using its leverage in the TPP, in the same way that it facilitated the Uruguay Round of negotiations by establishing the US-Canada FTA and NAFTA (see VanGrasstek, 2000). Emerging economies may have been forced to participate in the TPP for fear of being marginalised, and to accept its rules in multilateral negotiations. Thus, the regional rules embedded in the TPP would have become international rules in the long run.

\section{Problems for the TPP}

The TPP now faces many likely insurmountable challenges. Even before the rejection of the agreement by President Trump, it faced scepticism in the US. The TPP would only have involved a small increase in market access for the US. The official assessment report by US International Trade Commission (USITC) estimated that the US's real GDP in 2032 would be only 0.15 per cent higher as a result of the TPP (USITC, 2016, p. 22). Another report estimated that the TPP would only contribute to members' economies by about 1 per cent and their exports by $2-4$ per cent (Petri, Plummer \& Zhai, 2013, pp. 3-4). In fact, the limited new market access resulting from the TPP would hardly assist the TPP members to advance their economic ties with each other, thereby straining the resilience of the pact.

US President Trump confirmed that he would withdraw the US from the TPP on 21 November 2016. During his campaign, he called the TPP a 'potential disaster' from which he would withdraw when he took office (Dinan, 2016). To date, there is no indication that the Trump administration will consider revisiting the TPP negotiations. The Commerce Secretary Wilbur Ross regarded the TPP as a 'dumb deal' and favoured a bilateral FTA approach, considering that, in this way, the US could leverage market access to its huge market and acquire more concessions from its trading partners (Schott, 2016). This means that the Trump administration will not present the legislation necessary for US participation in the TPP to Congress. 
10. EVALUATION OF REGIONAL ECONOMIC INTEGRATION IN EAST ASIA






\section{Effects on East Asia}

The TPP has had a significant influence on East Asia. First, as the US is the biggest market for East Asian exports, almost all East Asian economies were concerned about being excluded from the TPP and discriminated against. Consequently, seven countries from East Asia joined the TPP as initial members and others expressed their interest in participating in the next round of negotiations. ${ }^{4}$

China was initially concerned about its exclusion, but developed a pragmatic approach known as a quaternity, or set of four, strategy. Specifically, China:

- adopted a 'wait and see' attitude to TPP negotiations

- proposed the negotiation of an investment agreement with the US

- established four free trade zones domestically (Shanghai, Guangdong, Fujian and Tianjin) to experiment with high-level liberalisation, with the aim of facilitating market opening throughout the country

- took more active steps in the RCEP negotiation in terms of regional actions. $^{5}$

In addition, China created the major 'One Belt and One Road' initiative, known as the Belt and Road Initiative (BRI), and the Asia Infrastructure Investment Bank (AIIB). Importantly, the BRI and the AIIB go beyond the traditional FTA approach for regional economic integration, and provide a different strategy for creating new growth engines by improving regional infrastructure (Gang, 2015).

The stance of ASEAN and the degree of consensus among its members will be crucial in responding to the challenges facing the TPP. By initiating RCEP, ASEAN ensured that it was a hub of the agreements and, thus, able to forcefully pursue its interests. In moving towards an integrated regional FTA, ASEAN may lose its centrality in regional integration. Considering the large economic disparities among its members, ASEAN needs to strengthen its capacity to engage other economies on an equal footing. Under its new charter, ASEAN established the goal to form

4 Australia and New Zealand are included in the East Asia group, as they participate in many economic integration and cooperation activities. The seven participating countries are Australia, New Zealand, Japan, Brunei, Singapore, Malaysia and Vietnam.

5 China favoured the ASEAN+3 framework (EAFTA) and led the EAFTA feasibility study during 2004-06. 
a strengthened ASEAN community by 2015-the ASEAN Economic Community (AEC) — along with Security and Social Communities. Thus, it seems likely that RCEP will be concluded and accepted by ASEAN only after it succeeds in building the AEC. The best strategy for concluding RCEP may be to support ASEAN's efforts to build the AEC.

Initially, Japan was hesitant about joining the TPP; however, following lengthy discussions and much study, and despite challenges from the TPP regarding Japan's sensitive domestic sectors, including agriculture, it decided to join in 2013. To strengthen its power in FTA negotiations and ensure that it would be included in the drafting of future international trade rules, Japan indicated its political interest in joining the TPP. According to one study, the welfare effects for Japan from the TPP and RCEP are almost the same (Petri et al., 2013). Thus, economic factors alone do not explain why Japan prefers the TPP as its priority FTA. There is a widely held belief that the TPP has strategic importance in strengthening the US-Japan alliance (Bergsten, 2016).

As an export-led economy, ROK is quite active in forging FTAs with its trade partners. It has concluded several important bilateral FTAs with large economies including the US, China and the EU. ROK has been cautious in joining the TPP. However, after the China-ROK FTA came into effect, ROK expressed its interest in joining the TPP, stating that it would strive to join the mega-FTA in any form (Ji-young, 2015). At the same, it stressed that the ROK government would determine the timing of its entry after thoroughly analysing the effects on its national economy of joining the TPP (Ji-young, 2015). In fact, new market access from the TPP was not significant for ROK, as it could acquire the same market access by concluding the ROK-Japan FTA. The main reason that ROK may have preferred to join the TPP was fear of being excluded from rule making in the region.

When the TPP negotiations concluded in 2015, much progress had also been made in the RCEP negotiations, although these failed to be concluded by 2016. Considering the large development gaps in East Asia, as well as the diversified economic needs of those involved in the negotiations, it was difficult for the 16 economies to reach consensus. However, President Trump's executive order ending the US's participation in the TPP—signed on 23 January 2017 (Tharoor, 2017) —may divert the focus of the ASEAN economies to the RCEP negotiations and assist in building momentum for the deal to be concluded more rapidly. 


\section{East Asia and WTO}

\section{WTO in perspective}

The global trading system is currently experiencing the largest round of reconstruction since the Uruguay Round. In the short term, owing to the comparatively low average most-favoured nation (MFN) tariffs of WTO members, costs will be high for developed countries to open up sensitive sectors and for developing countries to reform their behindthe-border measures. Therefore, the possibility of reaching a single undertaking of agreements in the Doha Round - the multilateral trade negotiation round at the WTO-is relatively low. The US joined and promoted TPP negotiations to create a comprehensive, modern template for future FTA negotiations. Its aims were to provide an alternative model for consolidating existing trade agreements (Petri et al., 2011, 2014) and to relaunch a new round of WTO negotiations. However, the rise of trade protectionism in the US and President Trump's attitude towards globalisation makes it unlikely that a new round of WTO negotiations will be launched. In addition, the High Level Trade Experts Group (2011) has argued that any efforts under a new round are unlikely to succeed.

In December 2013, 159 WTO members concluded negotiations on a Trade Facilitation Agreement at the Bali Ministerial Conference, as part of the wider Bali Package. The Trade Facilitation Agreement contained provisions for expediting the movement, release and clearance of goods, including goods in transit. It set out measures for effective cooperation between customs and other appropriate authorities on trade facilitation and customs compliance issues. Other provisions covered technical assistance and capacity building in this area. The Trade Facilitation Agreement in the Bali Package provided a timely lifeline for the multilateral trading system, the credibility of which was slowly being eroded (Kanyimbo, 2013). The benefits from the Trade Facilitation Agreement to the world economy are estimated to be between US $\$ 400$ billion and US $\$ 1$ trillion. These benefits arise from a 10-15 per cent reduction in trade costs and increases in trade flows and revenue collection, which create a stable business environment and attract foreign investment (WTO, 2013). To reap these benefits, priority needs to be given to this agreement; two thirds of members need to complete their domestic ratification process before the Trade Facilitation Agreement can enter into force. 
With multilateral negotiations on hold, more alternatives for negotiations are being explored. One of these alternatives can be seen in the form of sectoral agreements reached in the WTO. For instance, the Information Technology Agreement (ITA) and the sectoral protocols to the General Agreement on Trade in Services were negotiated under the terms of existing agreements and the benefits are extended on an MFN basis (VanGrasstek, 2013, p. 553). Many participating economies urged a swift conclusion to ongoing negotiations around the expansion of the ITA product coverage-that is, ITA 2. This agreement is expected to contribute to growth in international trade. If ITA 2 is concluded successfully, more effort could be directed to utilising this sectoral agreement approach to explore a multilateral investment agreement under the WTO framework.

\section{East Asia and multilateralism}

East Asia has a vital stake in maintaining open markets and its continued success depends on an open, rules-based global system of trade and investment. As East Asia's economic success has relied heavily on integration with the global market (Chia, 2010), all economies in East Asia will continue to be interested in supporting multilateralism. As East Asian regional production networks are based on a highly open structure, East Asian regionalism is not in conflict with multilateralism (Zhang \& Minghui, 2012).

By integrating into the global system, East Asian economies will benefit, not only from the liberalisation of manufactured exports, but also from the enhanced transparency and predictability of members' trade regimes. Although approximately 50 per cent of Asian exports go to markets outside the region, demand for final goods means consumption from outside economies accounted for more than 70 per cent of Asian exports in 2007 (ADB 2010). Thus, trade within the region is dominated by intermediate products. In fact, more than half of all intermediate goods are assembled in Asia (especially in mainland China) before they are consumed in external markets, including the EU and US. These two economies are the main destinations for Asia's final goods; in 2007, the US accounted for 23.9 per cent of Asia's total final goods and the EU accounted for 22.5 per cent. The Asian market only receives 28.9 per cent of its own final goods. It is notable that East Asian economies rely on exporting their products to outside markets - in particular, the US and the EU. Although proliferation of regional FTAs may assist East Asia to increase 
intra-regional trade, an open global market environment will continue to be important because the regional market is closely linked to the global market in many ways. Within production networks, it is multilateral arrangements rather than regional FTAs that benefit exporters in East Asia most.

Given the benefits that they receive from the multilateral trading system, East Asian economies have been reluctant to pursue regionalism. Since the late 1990s, East Asian economies have, understandably, felt compelled to negotiate their own agreements with critical markets in response to regionalism in other areas of the global economy, namely the EU and NAFTA. East Asian economies have feared that, unless they develop their own regional trade arrangements, they will be disadvantaged in global competition and multilateral negotiations. The push towards regionalism in East Asia strengthened considerably after the financial crisis in 1997. The silver lining of the crisis was that it created an East Asian economic identity because it highlighted the highly integrated nature of these economies (Kawai, 2005). As result, most of the FTAs in East Asia attach great importance to compliance with WTO principles. For instance, the Asia-Pacific Economic Cooperation forum (APEC, 2004) and the ADB (2008) have identified guiding principles for FTA best practice, which highlight consistency with GATT and WTO rules.

In practice, economies in East Asia are competing to negotiate FTAs with their trade partners to become hubs instead of spokes in the regional economy. Complex FTAs would potentially disrupt the processes of the cross-border production networks that have been central to the region's successful integration. Uncoordinated proliferation may lead to varying phase-in modalities and time frames for tariff concessions, as well as varying preferences across FTAs, especially on ROOs, which could hamper the process of production networking across economies in East Asia. RCEP is designed to deal with this noodle bowl of FTAs in the region. As Baldwin $(2006,2007)$ indicated, noodle bowls are building blocks on the path to global free trade, and a region-wide FTA that is GATT/WTO-consistent could eventually contribute to multilateralism.

East Asia's past economic success has relied heavily on an open and supportive global environment. Its rising integration within the global market has contributed significantly to the growth of international trade, and its commitments to the WTO and other international organisations could further deepen its integration and generate benefits for world 
economic development. Although East Asia needs to be cautious about its export-oriented growth model, and must consider how to rebalance its economy, its interest in the global market will not be reduced because its future economic dynamism will be closely associated with the global market environment. Nowadays, the world economy is threatened by sentiments against globalisation, apparent in phenomena such as Brexit and trade protectionism such as Trump's 'America First' rhetoric in the US. East Asia needs to fight against trade protectionism, which directly harms regional production networks. It must insist on unilateral liberalisation as well as regional integration to support free trade.

\section{China's strategy and role}

\section{China's opening strategy}

Since 1978, when reforms and opening began, opening to trade has played a key role in China's economic success. In 1986, China asked for a resumption of its member status in GATT. As GATT developed into the WTO in 1994, China, from 1995, had to negotiate its accession. The long negotiation and implementation process helped China to build a comprehensive foundation, based on an open market system. It also helped China to engage with the world market, using rules-based commercial behaviour. China strongly supports the multilateral system, as it benefits profoundly from its wide and deep engagement in the global market.

China has become active in forging FTAs with partners in East Asia and other regions in the world. To date, China has signed 14 FTA agreements, of which 12 have been implemented, covering 22 countries and regions from Asia, Latin America, Oceania and Europe. In addition, China has engaged in larger FTA negotiations, ranging from the China-JapanKorea trilateral FTA to RCEP. Further, China plans to take a leading role in promoting the Free Trade Area of the Asia-Pacific (FTAAP) under the APEC framework.

Although China has been a leader in initiating its ASEAN+1 FTA, as a developing economy, it has had difficulty in negotiating FTAs with large developed economies. Thus, China adopted a 'learning by doing' 
approach, concluding FTAs with New Zealand, Switzerland, Singapore and ROK. It has also proposed investment agreements with the US and EU.

In 2012, China adopted a more aggressive strategy to forge FTA networks in a global context. The state council issued its first comprehensive and strategic document on FTA construction, which clarified the short-, medium-and long-term goals of China, as well as the specific requirements for each time frame for FTAs in neighbouring areas and regions. As well as prioritising negotiating FTAs with neighbouring countries, China has made efforts to negotiate FTAs with economies from other parts of the world, especially emerging economies, large developing countries, main regional economic groups and some large developed countries.

\section{Belt and Road Initiative}

In a speech on the Silk Road Economic Belt at Nazarbayev University (Kazakhstan) on 7 September 2013, Chinese President Xi Jinping praised the role of the ancient Silk Road in building close economic, social and cultural links, and in bringing peace between China and the outside world. The president called on China and Kazakhstan to build a modern belt together-that is, transportation and economic corridors that connect China to Europe and all other major Eurasian sub-regions. Speaking to the Indonesian parliament on 3 October 2013, Xi put forward a proposal to build a twenty-first century maritime Silk Road to broaden trade and other economic connections between China and other maritime countries of South-East Asia, South Asia, the Middle East, East Africa and the Mediterranean. The two initiatives are part of a package that covers vast regions of Asia, Europe and Africa, linking both land and maritime regions, with comprehensive agendas ranging from infrastructure and industrial parks to port networks and cultural exchanges. The National Development and Reform Commission, the Ministry of Foreign Affairs and the Ministry of Commerce, with State Council authorisation, issued a policy document in 2015, known as the Belt and Road Initiative (Vision and actions, 2015). 
The BRI is not intended as a counterstrategy to the US 'pivot to Asia' strategy; rather, it is based on China's own needs. ${ }^{6}$ The BRI will help to develop new market opportunities, which are of great significance for China's economic restructuring. After more than three decades of high growth, the Chinese economy is altering to a 'new normal' statethat is, it is shifting from a high-growth period to a moderate-growth period. To create a new dynamic growth engine, it is important to build up demand-led growth momentum and explore external market opportunities. The new growth frontier of the global economy lies in developing countries. However, the most significant bottleneck for developing economies is poor infrastructure for industrial supply chains. As most of China's neighbours are developing economies, it would be beneficial to China if their economic environment could be improved through participating in the BRI. By financing the infrastructure and industrial zones, it is expected that the BRI will create new growth potential in the relevant areas of Europe, Asia and Africa. China can play a key role under the BRI because it possesses special advantages in providing investment capital and supplying equipment and technology. It also has experience in developing infrastructure network and industrial zones, which will provide opportunities for Chinese companies in their 'going outside strategy' (Yonghua, 2014).

Direct investment will assist the Chinese economy to become more integrated with other economies. Many labour-intensive factories in China need to relocate to low-cost countries to maintain their competitiveness, and developing countries in Asia and Africa want to develop their own manufacturing capacity by using their endowments of cheap labour. In contrast with the past model of moving 'dirty' industries out, China will build new industries together with local countries, as all projects under the BRI framework are to be designed and built jointly by China and the host countries. This new kind of development cooperation differs from the traditional aid-and market-based reallocation of outdated production capacities.

6 As observed by Pitlo (2015), the celebrated revival of the Silk Road would seem to herald the return of China's charm offensive, winning over neighbours and other countries in the region through increased trade incentives and transport connectivity. If developing a sound soft power strategy is the mark of a rising world power, does this mean China is on its way? 
The BRI is aimed at promoting orderly and free economic flows, an efficient allocation of resources and deep integration of markets, which would encourage the countries along BRI corridors to achieve economic policy coordination. It would further encourage them to achieve broader and more in-depth regional cooperation on higher standards and to jointly create an open, inclusive and balanced regional economic architecture. It is designed in the spirit of open regional cooperation and characterised by equality and mutual benefit, based on consultation, cooperation and sharing. The BRI seeks mutual benefit and will be 'open to all countries and international and regional organizations for engagement' (Ministry of Commerce, 2015).

Geographically, the Belt focuses on bringing together China, Central Asia, Russia and Europe (the Baltic nations), linking China with the Persian Gulf and the Mediterranean Sea through Central Asia and West Asia, and connecting China with South-East Asia, South Asia and the Indian Ocean. Its objective seems clear-cut and mission oriented. It will focus on jointly building a new Eurasian land bridge by developing economic corridors across China-Mongolia-Russia, China-Central Asia-West Asia, and the China-Indochina Peninsula. It will take advantage of international transport routes, rely on core cities along BRI corridors and use key economic industrial parks as cooperation platforms. The Road-which will focus on jointly building smooth, secure and efficient transport routes connecting major sea ports-is designed to go from China's coast to Europe through the South China Sea and the Indian Ocean, and from China's coast through the South China Sea to the South Pacific. The China-Pakistan and Bangladesh-China-India-Myanmar economic corridors will also be closely coordinated with BRI economies.

As the BRI is open and inclusive, its building process is open not just to countries along the routes, but also to all other countries in the world. As with the AIIB, the membership is open to all countries that have an interest in making a contribution. ${ }^{7}$ Thus, connectivity is not only limited to these routes; instead, it should be read as encompassing diverse connectivity across the Eurasian continent (Summers, 2016). The geographical coverage of the BRI is flexible, as the aim is to encourage

7 AIIB was established on 25 December 2015 with 57 initial members; 37 from Asia and 20 from other regions. 
a wide range of infrastructure development and socio-economic connectivity between China and those countries that are willing to participate.

Considering the economic diversity in the region, the BRI seeks to adopt a new model by closely connecting projects to the host country's development, as well as ensuring the efficient allocation of resources in China and in other countries. The economic development of most developing countries in the region has been hindered by inadequate infrastructure-the BRI is an important opportunity to break the bottleneck by designing and financing both in-country and cross-country highways and railway lines. A large number of projects are already being considered to connect various sub-regions, including high-speed railways, oil and gas pipelines and telecommunication and electricity links. Aside from direct financing from the Silk Road Fund and the AIIB, other financial institutions, including the $\mathrm{ADB}$ and the World Bank, will be actively involved because the BRI has established an inclusive framework, open to all who have an interest in participating. More importantly, it is the business community that is the major player; thus, both Chinese and foreign companies will be welcome to invest, based on established rules and a spirit of cooperation. The BRI, like many other initiatives, will face many challenges and difficulties, but China's aim is to do its best to succeed with the support of partners in the relevant areas.

\section{China and the multilateral trading system}

China's economic success has relied heavily on an open multilateral trading system. Following its entry into the WTO, China acquired significant economic benefits and its economy is now dependent on an open global system for trade, capital and resources. Although China has committed to change its export-oriented growth model and to create stronger internal demand, its interest in the global market will not be reduced because its future economic dynamism will be closely associated with the global market environment. China is likely to retain its 'number one' trade status even after domestic demand begins to play a major role in supporting economic growth.

China has contributed to the upkeep of the WTO and the maintenance of the principles of free trade, and also assists developing economies. It kept its promise to gradually eliminate tariffs and non-tariff barriers; this policy of openness has meant that China has maintained its trade 
growth rate at 20 per cent for many years. The development of China facilitated the growth of globalised production, leading to global welfare gains. Further, China actively participated in multilateral negotiations and helped developing countries by increasing flexibility around market access. In sum, China has strongly supported the current free trading system.

Although the Doha Round has been stalled for many years, and will likely never be completed as a multilateral round, China has not given up its confidence in the WTO processes. However, it is a complex developing economy simultaneously composed of low-performing and advanced sectors. Although China does not intend to abandon the WTO, it could act as an intermediary between developed members and developing ones. On 15 December 2015, President Xi Jinping stated that the multilateral trading system and regional trading arrangements were wheels that pushed economic globalisation. Regionalism will not impede multilateralism; rather, sooner or later, it will stimulate multilateral negotiation.

In retrospect, the new ITA negotiations, ITA 2, and the Environmental Goods Negotiations could not have been successfully concluded without China-US cooperation. In the future, a reconstruction of the global trading system is unlikely to succeed without consensus and cooperation between China and the US. The multilateral trading system remains the ideal trade policy paradigm. Properly managed, it can easily accommodate these two major economies. In this sense, the WTO is the most important component in maintaining the economic relations between China and the US. China and the US have a common stake in supporting a strong and resilient multilateral trading system. The challenge will continue to be uncertainty about the direction of US trade policy under President Trump.

\section{References}

Asian Development Bank (ADB). (2008, April). How to design, negotiate, and implement a free trade agreement in Asia. Mandaluyong City, Philippines: Asian Development Bank.

Asian Development Bank (ADB). (2010). Institutions for regional integration: Toward an Asian economic community. Mandaluyong City, Philippines: Asian Development Bank. 
Asian Development Bank (ADB). (2016). Integration indicators database. Retrieved from: aric.adb.org/integrationindicators

Asia-Pacific Economic Cooperation (APEC). (2004). Best practice of FTA/ RTAs in APEC. APEC Doc. No. 2004/CSOM/028rev.1, 2004. 16th APEC Ministerial Meeting, Santiago, Chile.

Baldwin, R. (2006). Multilateralising regionalism: Spaghetti bowls as building blocs on the path to global free trade. [Mimeographed]. Geneva, Switzerland: Graduate Institute for International Studies.

Baldwin, R. (2007). Managing the noodle bowl: The fragility of East Asian regionalism. ADB Working Paper Series on Regional Economic Integration No. 7. Retrieved from: www.adb.org/sites/default/files/ publication/28464/wp07-baldwin.pdf

Bergsten, C.F. (2016, 27 November). The Trans-Pacific Partnership and Japan, Nikkei Asian Review.

Bergsten, C. F. \& Schott, J. J. (2010, 25 January). Submission to the USTR in support of a Trans-Pacific Partnership agreement. Retrieved from: www.piie.com/publications/papers/paper.cfm?ResearchID $=1482$

Cheong, I. (2013, July). Negotiations for the Trans-Pacific Partnership agreement: Evaluation and implications for East Asian regionalism. ADBI Working Paper Series Negotiations No. 428. Tokyo, Japan: Asian Development Bank Institute.

Chia, S. Y. (2010, April). Trade and investment policies and regional economic integration in East Asia. ADBI Working Paper Series No. 210. Tokyo, Japan: Asian Development Bank Institute.

Dinan, S. (2016, 21 November). Donald Trump to withdraw US from Asian trade pact on his first day in office. The Washington Times. Retrieved from: www.washingtontimes.com/news/2016/nov/21/ donald-trump-withdraw-us-trans-pacific-partnership/

Gang, A. (2015). East Asian cooperation under the perspective of 'one belt, one road'-An interview with Zhang Yunling, the Professor of Chinese Academy of Social Sciences. World Affairs, 07, 32-34.

Goodman, M. P. (2013, 14-15 November). US economic strategy in the Asia-Pacific region: Promoting growth, rules, and presence. Paper prepared for CNCPEC seminar. Beijing, China. 
High Level Trade Experts Group. (2011, January). The Doha Round: Setting a deadline, defining a final deal, Interim report. Retrieved from: voxeu. $\mathrm{org} / \mathrm{sites} / \mathrm{default} /$ files/file/doha-round-setting-deadline-defining-finaldeal-interim-report-jan-2011.pdf

Horn, H., Mavroidis, P. C. \& Sapir, A. (2010). Beyond the WTO? An anatomy of EU and US preferential trade agreements. The World Economy, 33(11), 1565-88. doi.org/10.1111/j.1467-9701.2010. 01273.x

Japan External Trade and Research Organization. (2015). JETRO global trade and investment report. Tokyo, Japan: Government of Japan.

Ji-young, S. (2015, 6 October). Korea looking to join TPP. The Korea Herald. Retrieved from: www.koreaherald.com/view.php?ud=2015 1006001111

Kanyimbo, P. (2013, December). Trade facilitation in the Bali Package: What's in it for Africa? ECDPM Briefing Note No. 61. Retrieved from: ecdpm.org/wp-content/uploads/BN-61-Trade-Facilitation-BaliWhat-is-in-it-for-Africa.pdf

Kawai, M. (2005). East Asian economic regionalism: Progress and challenges. Journal of Asian Economics, 16, 29-55. doi.org/10.1016/j. asieco.2005.01.001

Kawai, M. \& Wignaraja, G. (2007). ASEAN+3 or ASEAN+6: Which way forward? ADBI Discussion Paper No. 77. Tokyo, Japan: Asian Development Bank Institute.

Kawai, M. \& Wignaraja, G. (2009, August). Asian FTAs: Trends and challenges. ADBI Working Paper Series No. 144. Tokyo: Asian Development Bank Institute. Retrieved from: www.adb.org/sites/ default/files/publication/155999/adbi-wp144.pdf

Lee, H. \& Itakura, K. (2014, 5 June). TPP, RCEP and Japan's agricultural policy reforms. Osaka School of International Public Policy Discussion Paper No. 14E003. Osaka, Japan: Osaka University.

Ministry of Commerce. (2015). Belt and road. Retrieved from: english. mofcom.gov.cn/article/zt_beltandroad/ 
Obama, B. (2015, 20 January). Remarks by the President in the State of the Union address [Transcript]. Retrieved from: www.whitehouse.gov/ the-press-office/2015/01/20/remarks-president-state-union-addressjanuary-20-2015

Obama, B. (2016a). State of the Union address as delivered [Transcript]. Retrieved from: obamawhitehouse.archives.gov/the-press-office/2016/ 01/12/remarks-president-barack-obama-\%E2\%80\%93-prepareddelivery-state-union-address

Obama, B. (2016b, 2 May). The TPP would let America, not China, lead the way on global trade. Washington Post. Retrieved from: www. washington post.com/opinions/president-obama-the-tpp-wouldlet-america-not-China-lead-the-way-on-global-trade/2016/05/ 02/680540e4-0fd0-11e6-93ae-50921721165d_story.html

Petri, P. A., Plummer, M. G. \& Zhai, F. (2011, 24 October). The TransPacific Partnership and Asia-Pacific integration: A quantitative assessment. East-West Center Working Papers, Economics Series No. 119. Honolulu, HI: East-West.

Petri, P. A., Plummer, M. G. \& Zhai, F. (2013, 7 March). Adding Japan and Korea to TPP_Asia-Pacific trade. Retrieved from: asiapacifictrade.org/ wp-content/uploads/2013/05/Adding-Japan-and-Korea-to-TPP.pdf

Petri, P. A., Plummer, M. G. \& Zhai, F. (2014). The TPP, China and the FTAAP: The case for convergence. In T. Guoqiang \& P. A. Petri (Eds.), New directions in Asia-Pacific economic integration (pp. 84-85), Honolulu: East-West Center.

Pitlo, L. B. (2015, 17 February). China's 'One belt, one road' to where?' The Diplomat. Retrieved from: thediplomat.com/2015/02/chinasone-belt-one-road-to-where

Schott, J. J. (2016, 5 December). TPP can be fixed if you know what's wrong with it. Retrieved from: piie.com/blogs/trade-investmentpolicy-watch/tpp-can-be-fixed-if-you-know-whats-wrong-it

Summers, T. (2016). China's 'new silk roads': Sub-national regions and networks of global political economy. Third World Quarterly, 37(9), 1628-43. doi.org/10.1080/01436597.2016.1153415 
Tharoor, I. (2017, 24 January). Trump kills TPP, giving China its first big win. The Washington Post. Retrieved from: www.washingtonpost. com/news/worldviews/wp/2017/01/24/trump-kills-tpp-giving-chinaits-first-big-win/

US International Trade Commission. (2016, May). Trans-Pacific Partnership agreement: Likely impact on the US Economy and on specific industry sectors. Retrieved from: www.usitc.gov/publications/ 332/pub4607.pdf

VanGrasstek, C. (2000). US plans for a new WTO round: Negotiating more agreements with less authority. The World Economy, 23(5), 673-700. doi.org/10.1111/1467-9701.00296

VanGrasstek, C. (2013). The history and future of the World Trade Organization. Geneva: World Trade Organization Publications.

Vision and actions on jointly building belt and road. (2015, 28 March). Retrieved from: news.xinhuanet.com/english/china/2015-03/28/c_ 134105858_2.htm

Wignaraja, G. (2014). The Regional Comprehensive Economic Partnership: An initial assessment. In T. Guoqiang \& P. A. Petri (Eds.), New directions in Asia-Pacific economic integration (pp. 84-85), Honolulu, HI: East-West Center.

World Trade Organization (WTO). (2013). Days 3, 4 and 5: Round-theclock consultations produce 'Bali package'. Retrieved from: www.wto. org/english/news_e/news13_e/mc9sum_07dec13_e.htm

World Trade Organization (WTO). (2017). Trade facilitation. Retrieved from: www.wto.org/english/tratop_e/tradfa_e/tradfa_e.htm

Xiangyun, X. (2010). Role of origin in East Asian FTA system and East Asian production system. Journal of Contemporary Asia-Pacific Studies, $1,29-44$.

Yonghua, S. (2014). BRI leads China's companies to go abroad. Retrieved from: world.people.com.cn/n/2014/1227/c1002-26285988.html

Zhang, Y. \& Minghui, S. (2012). Emergence of ASEAN, China and India and the regional architecture. China \& World Economy, 20(4), 92-107. doi.org/10.1111/j.1749-124x.2012.01297 
10. EVALUATION OF REGIONAL ECONOMIC INTEGRATION IN EAST ASIA

Zhang, Y. \& Minghui, S. (2013, June). FTAs in the Asia-Pacific: A Chinese perspective. Kokusai Mondai (International Affairs), 622. 
This text is taken from Asian Economic Integration in an Era of Global Uncertainty, edited by Shiro Armstrong and Tom Westland, published 2018 by ANU Press, The Australian National University, Canberra, Australia. 